\title{
Overview of Manually Operated Paddy Transplanter
}

\author{
Mr. A. V. Sutar ${ }^{1}$ \\ 1Assistant Professor \\ 1 Department of Mechanical Engineering \\ 1 D.K.T.E. Society's T.E.I., Ichalkaranji
}

\begin{abstract}
:
Agriculture is the most important sector in the Indian economy. It is the most important source of employment for most of the country's labor force. In 2012, about $49 \%$ of the labor force was engaged in agriculture. The highest proportion of these is in the rice sector. Rice is the country's main stable food. The release of labor to sectors other than agriculture is important to the development of the country. The mechanization of rice fields has played an important role in liberating labor.

Feeding a growing population is a huge challenge. The import of rice will cause the country's economy to drain. The mechanization of the rice sector will lead to higher productivity and release labor to other sectors. The goal of the project is to design a rice transplanting mechanism for small farmers in the country to transplant rice seedlings.
\end{abstract}

Key Words: Paddy Transplanter, Mechanical Device, Design, Fabrication.

\section{Introduction:}

The main sector in India is the agricultural sector. Rice is the main crop in the agricultural sector. The latest data from the Ministry of Agriculture shows that the 2014 rice output is expected to be 88.02 million tons, a $4 \%$ decrease from last year. This indicates that the yield has declined moderately during this period. The total planted area of Khalif this season was 10192 million hectares, which was lower than the 10446 million hectares in the same period last year. Officials say the good monsoon subsidence in parts of northern and central India has promoted planting. According to the government's first advance estimate, due to the imbalance of the southwest monsoon in the first half of the year, India's 2014-15 harif season's grain output is expected to decrease by 9 million tons from the same period last year to 120.27 million tons. The 2014 season. As of September 29, the monsoon was about $12 \%$ lower than normal, which was a significant improvement from the $40 \%$ deficit in July. The labor force plays a huge role in determining the method of rice establishment.

\section{Establishment method}

There are two ways to grow rice in India. Those are

Direct sowing/seeding and transplanting. 


\section{Live broadcast/seeding}

There are two types

1. Wet sowing

2. Dry broadcast

\section{Wet sowing}

Sow the pre-germinated seeds on a level field with puddles without standing water. The base fertilizer should be mixed while stirring. The seedlings should be irrigated when they are about 5 $\mathrm{cm}$ high. The stand established by this method varies with the quality of the site preparation, weed competition, water management and rainfall in the early stage after sowing.

\section{Dry broadcast}

Ungerminated dry seeds are sown into dry soil in rows or randomly. The seed rate usually varies with the severity of the environment and the type of physical damage to the seeds. The sowing rate varies from $150 \mathrm{Kg} / \mathrm{ha}$ to $300 \mathrm{Kg} / \mathrm{ha}$, depending on the degree of weed infestation in dry rice. There are two methods for live broadcast/seeding, manual or mechanical, and can also be subdivided into two categories:

\section{a) Row seeding}

This method follows the uniform spacing between plants. This will require uniform spacing in the planting guidelines. If a mechanical planter is used, ungerminated seeds must be used.

\section{b) Random seeding}

In this method, seeding is done without a certain distance. It is also called broadcast. This is a highly practiced method in India.

Advantages of live broadcast

- Need less labor

- Direct seeding plants mature 7 to 10 days earlier than transplanted rice

- Build a factory

- No impact on plant transplantation

- Method suitable for short-term varieties

Disadvantages of live streaming

- Need more seeds 
- Seeds may come into contact with birds, mice and snails

- Due to the similar age of rice and weeds, the competition for crop weeds is more intense

- Mechanical weeding is difficult

- Floods and droughts can damage seeds

\section{Migration}

In this method, the seeds are sown in one place, and then the seedlings that have grown a little are transplanted to another place. This is done to obtain higher yields and less weeding. In India, the scope of transplanting rice is decreasing due to scarcity of labor and resources, and the reduction of rice varieties in 4-4 $1 / 2$ months. Manual transplantation is labor-intensive, requiring 250-350 man-hours per hectare, accounting for 25\% of the total labor demand for crops. The rice transplanter has the problems of poor traction, sinking, and poor steering. The efficient work of the self-propelled rice transplanter requires suitable soil conditions, optimal soil depth, soil level and soil strength. Transplantation will reduce the ability to withstand water stress. It is recommended to transplant 4-4 $1 / 2$ months of varieties. When transplanting 3 months of varieties, seedlings should be planted. It is recommended to transplant when the site preparation does not meet the standards and the water management is not good. Compared with broadcasting, the reason why the transplanting of long-age varieties showed higher yield is that the transplanting reduces the excessive accumulation of nutrient biomass caused by transplanting shock.

\section{Nursery System}

The nursery uses $15-20 \%$ of the total cultivated land area. When preparing the seedbed, the surface needs to be flat, free of weeds, and well-drained. A small amount of nitrogen and phosphate fertilizers can be applied to the nursery. The seeding rate varies from 400 to $800 \mathrm{~kg}$ per hectare of nursery, depending on the location, soil type and seed quality. The choice of a particular nursery system depends on the availability of water, labor, land, and farming tools.

There are 5 transplanting nursery systems:

- Wet bed nursery

- Dry bed nursery

- dapog or mat nursery

- Bubble Pan Nursery

- Mechanical transplanting nursery box

\section{A) Wet bed method}

Wet bed nursery is mainly used in areas with sufficient water sources. Sow the pre-germinated seeds on the soil that has been thoroughly mashed and leveled. Drains must be constructed to 
properly drain the water. Adding organic fertilizer (decomposed) and a small amount of inorganic fertilizer as base fertilizer can increase the ease of uprooting of seedlings and the vigor of seedlings. The total seed bed area is about $1 / 10$ of the transplanted area, and about 100 kilograms of seeded rice fields are needed per hectare. The sowing amount of small-grain varieties should be adjusted. The nursery field should be free of shade and adequate drainage and irrigation facilities. High-quality rice seeds should be soaked in clean water for at least 24 hours, and then incubated in a warm and dry place for about 48 hours. Then spread the germinated seeds evenly on the nursery bed. Before planting, the nursery should be completely drained. Thereafter, the nursery should be kept in humid conditions for about 5 days. After the seedlings grow up, store water in the nursery and gradually raise the water level. The best period for transplanting seedlings is about 15-21 days. The nursery should be free of weeds, pests and diseases and nutritional deficiencies. If this happens, it must be treated at the nursery level.

\section{B) Dry bed method}

The nursery is prepared under dry soil conditions. Prepare the seed bed with a suitable size and raise the soil to a height of about $5-10 \mathrm{~cm}$. A thin layer of half-burned rice husk can be laid on the seedbed to facilitate uprooting. Sow dry or just germinated seeds in rows, about $10 \mathrm{~cm}$ away from the dry seedbed. You can also sow at will, but because weed control is difficult, it should not be encouraged. The site needs adequate irrigation facilities and no shade. The nursery area should be about $1 / 10$ of the transplanted area. The seed rate is higher than the wet bed method (approximately $150 \mathrm{~kg} / \mathrm{ha}$ ) because the germination rate may be lower. Root removal of seedlings should be carried out between 15-21 days after germination. The water stress in the nursery should be eliminated. If the soil nutrient content is low, it is recommended to mix base fertilizer. The advantage of this method is that the seedlings are short and sturdy, and the root system is longer than the wet bed, which can grow even in heavy rain, which cannot be achieved by the wet bed. A major disadvantage is that these roots may be damaged during the pulling process. Seedlings in highland nurseries may also be infected with rice blast, making them more susceptible to pests such as rodents.

\section{C) Dapog method.}

This method can be built on a flat surface. If lowland paddy fields are used, water supply and control should be very reliable. The required area is approximately 10 square meters per hectare of transplantable land. Dapog method requires much smaller area than traditional nursery. The sowing rate is about $125 \mathrm{Kg} / \mathrm{ha}$. A flat seed bed should be made, and the center of the bed should be slightly higher than the edge to allow water to drain from the surface. It is recommended to use banana leaves without ribs, polyethylene sheets or any flexible material to cover the surface to prevent seedling roots from penetrating into the bottom soil layer. Cement floors can also be used for the same purpose. Burned rice husks or compost are used to cover seed beds about 1/4 inch thick. Sow the germinated seeds evenly on the seed bed with a thickness of 2-3 grains and a density of $700-1000 \mathrm{~g} / \mathrm{m} 2$. Spray the germinated seeds with water and press them by hand or a wooden plate for up to 3-4 days in the morning and afternoon to prevent uneven growth. If the seeds are sown without litter and the temperature is lowered, frequent irrigation is required. Transplanting in the nursery should be carried out 12-14 days after the seeds germinate. The 
advantage of "dapog" over wet/dry bed nurseries is that it requires less area and has the lowest cost of uprooting seedlings. However, since the seedlings are small, transplanting is difficult. The seedlings of dapog nurseries are less impacted by transplanting than other nurseries, so these seedlings are more suitable for short-age varieties. Another disadvantage of dapog seedlings is that the field should be very flat and without water, because the seedlings are very short.

\section{D) Bubble Pan Nursery}

The bubble tray nursery is a good system for growing 12-15 day old seedlings with "root balls". These trays have 434 stoppers (miniature pots with a diameter of $1.3 \mathrm{~cm}$ and a depth of $1.3 \mathrm{~cm}$ ) with a small hole at the bottom to facilitate the movement of water and nutrients from the soil below to the plug through capillary action. The soil is filled into pots with 2-3 seeds per pot. When the seedlings grow to 14-21 days, they are thrown into the field for planting at any interval. 400-750 pallets are required per hectare of rice.

\section{E) Mechanical transplanting nursery box}

Mechanized transplantation requires a different technique than manual transplantation. Usually use a nursery box suitable for the type of transplanter. In the nursery box, the seedlings grow on a thin layer of soil in a $33 \mathrm{~cm} \times 5 \mathrm{~cm}$ plastic tray. In some cases, seedlings will grow on a larger area and then cut into rectangular strips (seedling pads) suitable for transplanting machine planting trays. In terms of details, rice transplanting is superior to other methods because they have some advantages. When performing manual transplantation, labor shortage is a major problem. The mechanical transplanting of rice seedlings requires high capital and skilled labor, and since common machines require a relatively large land area, land area has also become a problem. Mechanical transplanter is a better solution for Sri Lanka's national conditions. Still the problem Lenovo's situation should be resolved. These are high capital, line spacing, machine weight, and machine size.

\section{Rice intensification system (SRI method)}

The SRI method was developed to fully realize the potential of rice and obtain high yields. The method expects to achieve five goals.

- Plants should have more tillers

- The number of effective tillers should be more

- Ear length and grains per ear should be higher

- The grain weight should be larger

- The root system should grow broadly and healthy, this method has 6 attributes

- Widely grown

- Fewer seeds

- Transplant seedlings 
- Less water

- Bring weeds back to the soil

- Use of organic fertilizer

The inter-line and intra-line spacing used in the SRI method differs depending on the variety, and are $25 \times 25 \mathrm{~cm}, 30 \times 30 \mathrm{~cm}, 40 \times 40 \mathrm{~cm}$, and $50 \times 50 \mathrm{~cm}$. The spacing is higher than the normal transplanting method. Any rice variety can be cultivated in this way. The sowing rate is about 10 $\mathrm{kg} / \mathrm{ha}$.

Advantages of SRI

- Reduce seed demand and save seed cost

- Irrigation and water saving-using dry method

- Since no chemical fertilizers and pesticides are used, external input costs are reduced

- Low incidence of pests and diseases because the soil is allowed to dry intermittently

- Due to organic farming methods, rice is healthier and more delicious.

- Increased yield due to a large number of tillers, increased ear length and grain weight

- Use a smaller number of parents for seed propagation

- Farmers can produce their own high-quality seeds shortcoming

- Higher labor demand

- High production cost

- Time-consuming method

\section{Literature survey}

Worldwide, the use of agricultural equipment is increasing. In the use of agricultural equipment, India only accounts for $10 \%$. Due to the scarcity of manpower and the need for more time for transplantation to reduce this problem, we decided to do agriculture-related projects. In order to learn more about today's agricultural equipment and methods, we searched and researched some papers and visited agricultural equipment manufacturing companies. 
The searched and researched papers are listed in the table. 2.1:

\begin{tabular}{|c|c|c|c|c|}
\hline $\begin{array}{l}\text { Sr. } \\
\text { No }\end{array}$ & Title of Paper & Author & $\begin{array}{l}\text { Year of } \\
\text { publish }\end{array}$ & Remark \\
\hline 1 & $\begin{array}{l}\text { Design \& fabrication of } \\
\text { sunflower seed extracting } \\
\text { machine }\end{array}$ & $\begin{array}{l}\text { Azharuddin Kazi, } \\
\text { Mir Safiulla, } \\
\text { Narasimamhan } \\
\text { Manohar, } \\
\text { Pavan Kumar }\end{array}$ & $\begin{array}{l}\text { June } \\
2016\end{array}$ & $\begin{array}{l}\text { 1.Design } \\
\text { calculation } \\
\text { 2.Fabrication }\end{array}$ \\
\hline 2 & $\begin{array}{l}\text { Design \& Development of } \\
\text { manually operated seed } \\
\text { planter machine }\end{array}$ & $\begin{array}{l}\text { Kyada A. R., } \\
\text { Patel D.B. }\end{array}$ & $\begin{array}{l}\text { Dec } \\
2014\end{array}$ & $\begin{array}{l}\text { 1.Mechanism } \\
\text { used } \\
\text { 2.Power } \\
\text { transmission }\end{array}$ \\
\hline 3 & $\begin{array}{l}\text { Design \& Fabrication of } \\
\text { small scale sugarcane } \\
\text { harvesting machine }\end{array}$ & $\begin{array}{l}\text { Adarsh J Jain, } \\
\text { Shashank Karne, } \\
\text { Shrinivas Rathod }\end{array}$ & $\begin{array}{l}\text { July } \\
2013\end{array}$ & $\begin{array}{l}\text { 1.Design } \\
\text { 2.Material } \\
\text { selection } \\
\text { 3.Result } \\
\text { analysis }\end{array}$ \\
\hline 4 & $\begin{array}{l}\text { Design a small scale grain } \\
\text { harvester }\end{array}$ & $\begin{array}{l}\text { Christopher Boyle, } \\
\text { Ian Jutras, } \\
\text { Earl Ziegler }\end{array}$ & $\begin{array}{l}\text { April } \\
2012\end{array}$ & $\begin{array}{l}\text { 1.Desigining } \\
\text { 2.Mechanism }\end{array}$ \\
\hline 5 & $\begin{array}{l}\text { Ergo-Economical Analysis } \\
\text { of different paddy } \\
\text { transplanting operation }\end{array}$ & $\begin{array}{l}\text { S. Pradhan, } \\
\text { S.K. Mohanty }\end{array}$ & $\begin{array}{l}\text { Jan } \\
2014\end{array}$ & $\begin{array}{l}\text { 1.Comparisio } \\
\mathrm{n} \\
\text { 2.Analysis } \\
\text { 3.Mechanism } \\
\mathrm{s}\end{array}$ \\
\hline 6 & Agricultural Machinery & Sukhpal Singh & $\begin{array}{l}\text { April } \\
2009\end{array}$ & $\begin{array}{l}\text { 1.Machinery } \\
\text { variations \& } \\
\text { linkage }\end{array}$ \\
\hline 7 & $\begin{array}{l}\text { Design, Modification \& field } \\
\text { testing of groundnut digger }\end{array}$ & $\begin{array}{l}\text { M. Taussef Asghar, } \\
\text { Abdul Ghafoor, } \\
\text { Anjum Munir }\end{array}$ & $\begin{array}{l}\text { July } \\
2014\end{array}$ & $\begin{array}{l}\text { 1.Material \& } \\
\text { methods used }\end{array}$ \\
\hline
\end{tabular}

\section{Literature review}

The rice transplanter is a special machine used for transplanting rice in the field. A common rice transplanter includes:

- Seedling trays like shed roofs are set up with pad rice nurseries.

- Seedling tray mover that moves the seedling tray like a typewriter. 
- Multiple picking forks, pick up seedlings from the cushion nursery on the nursery tray and put the seedlings into the soil, as if the seedlings were taken out between human fingers. The use of rice transplanter for machine transplanting requires much less time and labor than manual transplanting. It increases the approximate area that a person can plant from 700 square meters per day to 10,000 square meters per day (en.wikipedia.org/). Transplanting rice seedlings can be divided into the following three categories:

1. Manual (manual)

2. Manual operation of the machine (manual operation)

3. Mechanically operated machines (working on engine power)

\section{Manual migration}

This method is suitable for small fields and padding patches. Manual transplanting does not require expensive machinery, and is most suitable for labor surplus areas and small rice fields. Manual transplanting can be carried out in fields where the level is not ideal and the water level changes. Seedlings are cultivated in wet, dry or modified mat nurseries. Proper nursery management will produce healthy, vigorous seedlings.

Limitation:

- Transplantation is tedious and time-consuming (up to 30 person-days/ha)

- Planting workers may have back problems (health risks)

- Difficult to obtain enough labor force to plant on time during peak periods

- It is difficult to maintain optimal spacing and uniform plant density, especially for random transplants and contract workers.

- The low plant density of area-based contract transplantation reduces yields.

- In rainfed areas, seedlings (especially modern varieties) may become too old before the rain falls and the ground is ready for planting

\section{Manual transplantation machine}

The manually operated translator is driven by manpower. The operator must move with the rice transplanter and manually power the machine. These machines are small enough to be operated manually.

3. General information: The machine consists of a seedling tray, fork, handle and slide plate. By pressing the handle, the fork will pick up the seedlings and plant them into 6 rows. Every time the handle is struck, the seedling tray will move its side so that the seedlings can be picked evenly with a fork. The operator must pull the machine while punching the handles at the 
required spacing. The line spacing is $200 \mathrm{~mm}$. A manual rice transplanter made in China is shown in Figure 2.

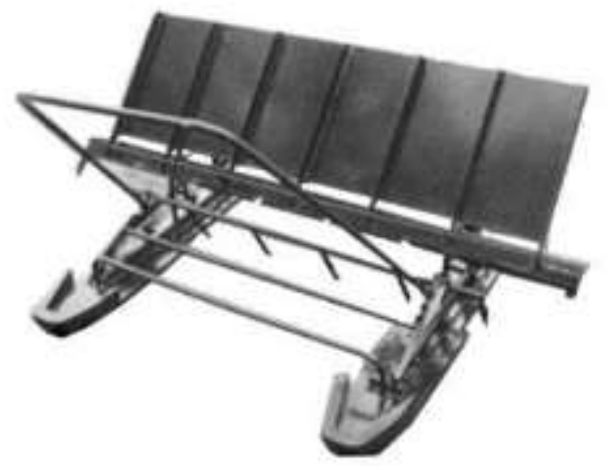

Figure 1: Hand powered mechanical transplanter

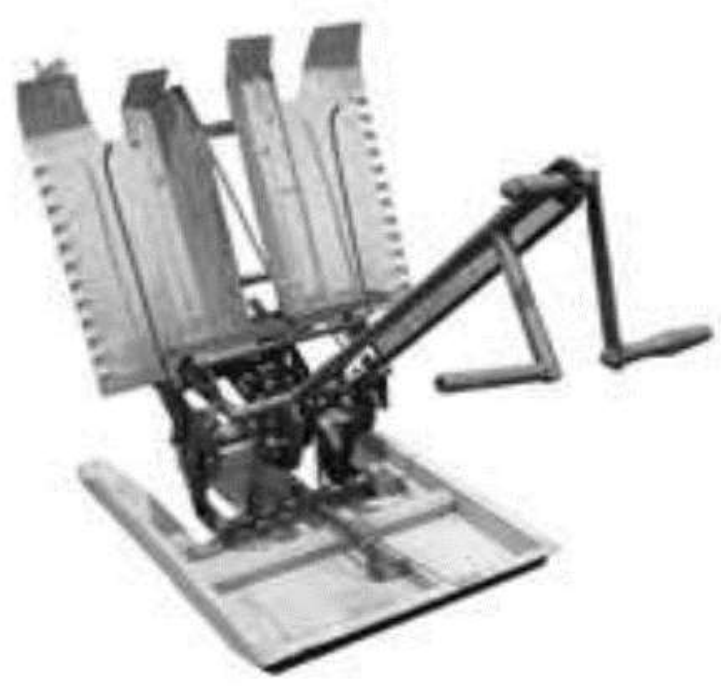

Figure 2: Hand cranked rice transplanter

This is the backward type. It can be planted in 2 rows at the same time. The row spacing is 250 $\mathrm{mm}$, and the planting distance is adjustable. The specifications of the transplanter are as follows:

The transplanter is specially designed for transplanting naked plants without mud. The plants in the nursery should be taken out after washing away the soil or mud. The machine is operated by one hand, and the other is pulled by hand. It has a very lightweight structure, which is easy to operate and maintain. This machine is used by small-scale farmers in China.

\section{Engine-operated transplanter}


The translator operated by the engine is powered by the engine. The operator must move with the transplanter, or in some cases, the operator can sit on it. Hand-held engine-operated transplanters are light enough to be operated by one operator, while other types of transplanters carry one or more laborers to operate and add mats to trays. The engine transplanters produced in industrialized countries such as China, Japan, South Korea, and India are not suitable for Sri Lanka's conditions, because our farmers use different field conditions and spacing, and the machine costs are higher. There are two kinds of engine-operated transplanters

1. Walk behind the rice transplanter

2. Self-propelled rice transplanter (riding type)

\section{Walk behind the rice transplanter}

This type of rice transplanter (Figure 2.3) requires the operator to walk behind to operate. (Kubota rice transplanter) The rice transplanter consists of a prime mover, a transmission device, an engine, a float, a tug, a seedling tray, a seedling tray shifter, a tuning fork and a tuning fork cleaner. The mat nursery is used to transplant evenly without damaging the seedlings. The planting depth and mountain distance can be adjusted. Automatic depth control helps maintain uniform planting depth. The machine has a safety clutch mechanism, which can prevent the planting device from being damaged by the impact of rocks in the field. During operation, the machine is transported to the field, and the mat nursery is loaded into the tray of the transplanter. The machine enters transplanting mode and operates in the muddy field. The performance of the transplanter is to check the distance from the mountain to the mountain, the planting depth and the number of seedlings per mountain within 2-3 m after transplanting. If the transplanting is normal, the machine will run in the normal transplanting operation.

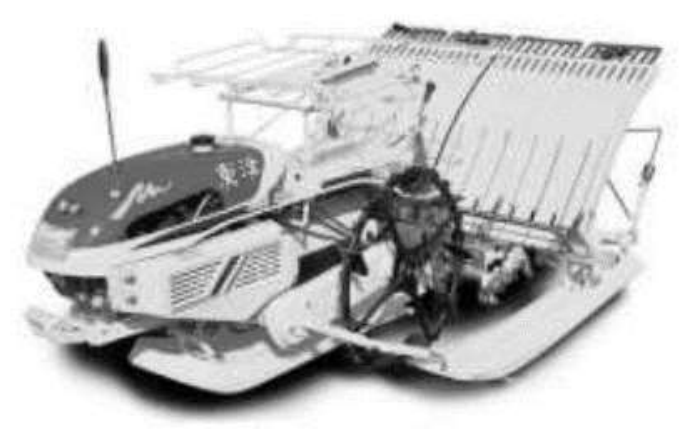

Figure 3: Walking behind type mechanical rice transplanter

\section{Self-propell rice transplanters (Riding type)}

These types of transplanters are capable to carry operators on the machine. A single wheel driven transplanter is shown in the Figure 2.4.A. 
It is equipped with a diesel engine. The machine transplants the seedlings from the cushion nursery to eight rows at a time. The driving wheels receive power from the engine through the Vbelt, cone clutch and gearbox. The drive shaft from the gearbox powers the transplanting mechanism mounted on the float. The float helps the transplanter to slide on the muddy surface.

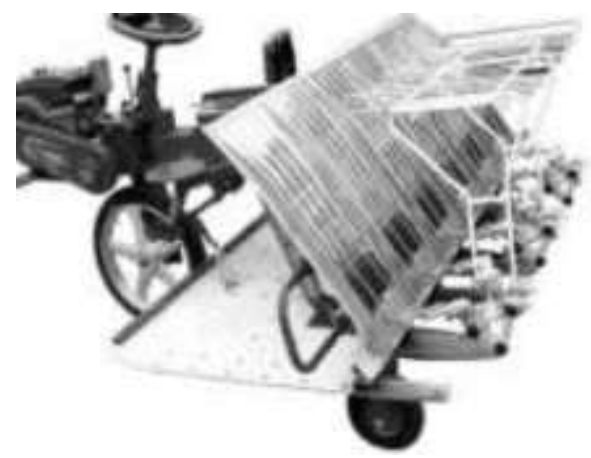

Figure 4.A: Self-propell type rice transplanter

The 8-row cushion nursery tray is moved sideways by a scroll shaft mechanism, which converts the rotational motion received from the engine through the pulley, gear and cardan shaft into the linear motion of the rod connected to the seedling tray, which can provide the tray After reaching the extreme position at the end, reverse the direction of movement of the pallet. The fixed fork with knock-out rod type planting finger (crank type) moves through a four-bar linkage mechanism to locate the designed trajectory to the tip of the planting finger.

A four wheel, riding type transplanter is shown in the Figure 2.4.B.

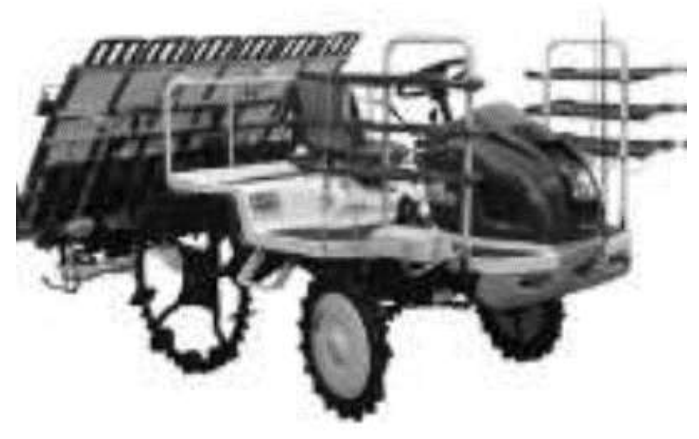

Figure 4.B: Self-propell type rice transplanter

It is a six-row rice transplanter using pad type seedlings. The double-acting transplanting mechanism is operated by a sun gear and four planetary gears. The machine can adjust the number of seedlings per mountain, the depth of transplanting and the distance from mountain to mountain. Automatically keep the transplanting depth constant during the transplanting process. The row spacing is $300 \mathrm{~mm}$, and five sets of mountain distances ranging from 120 to $220 \mathrm{~mm}$ can be fixed according to the required plant population. The machine is equipped with six spare 
seedling racks for intermittent filling of trays. The machine is powered by a 12-horsepower aircooled gasoline engine and is equipped with power steering. The transplanting depth can be set from 15 to $45 \mathrm{~mm}$. Research problem

Mechanical rice transplanting is a solution to solve the current situation in India, free up labor, and reduce the cost of rice production. Farmers are aware of the advantages of rice transplanting over broadcasting. But due to the high scarcity of labor, they are unable to practice. The transplanting machines available in the country are still imported. The engine-driven rice transplanter is costly, and the spacing between raw materials is fixed, which is not suitable for Indian conditions. The existing manual transplanter is inefficient. The main reason for poor acceptance is low machine capacity. A simple engine-operated rice transplanter or manually operated rice transplanter with an average of one hectare per day would be a better solution.

Target

The main goals of the project are:

- Design a mechanism for transplanting rice seedlings

- Test the performance of the migration mechanism

\section{Future scope}

In the future, this project may encounter many changes, such as automatic or semi-automatic systems, where the motor runs at a constant speed instead of manually providing power.

\section{Conclusion:}

The rice seedling transplanting machine works satisfactorily. However, there is still some improvement work to be done before introducing it to farmers. The machine is driven by human power, but can be connected to an engine to improve performance. It is possible to transplant multiple lines to the development machine at the same time.

\section{REFERENCES}

[1] "Design \& fabrication of sunflower seed extracting machine", by Azharuddin Kazi , Mir Safiulla, Narasimamhan M Manohar, International Journal of Latest Technology in Engineering, Management \& Applied Science (IJLTEMAS) Volume V, Issue VI, June, 2016

[2] "Design \& Development of manually operated seed planter machine", by Kyada A. R., Patel D.B., $5^{\text {th }}$ International \& 26th All India Manufacturing Technology, Design and Research Conference (AIMTDR 2014), IIT Guwahati, Assam, India, December 12th-14th, 2014 
[3] "Design \& Fabrication of small scale sugarcane harvesting machine", by Adarsh J Jain, Shashank Karne, Shrinivas Rathod., Int. J. Mech. Eng. \& Rob. Res. 2013 ISSN 2278 - 0149 www.ijmerr.com Vol. 2, No. 3, July 2013

[4] "Design a small scale grain harvester", by Christopher Boyle, Ian Jutras, Earl Ziegler., An Interactive Qualifying Project submitted to the faculty of Worcester Polytechnic Institute in partial fulfillment of the requirements for the Degree of Bachelor of Science. April 28, 2012

[5] "Ergo-Economical Analysis of different paddy transplanting operation", by S. Pradhan, S.K. Mohanty, IOSR Journal of Agriculture and Veterinary Science (IOSR-JAVS) e-ISSN: 23192380, p-ISSN: 2319-2372. Volume 6, Issue 6, PP 23-27 ,Jan. 2014. 